\title{
The GentLest OF GenTLEMEN
}

\author{
BY MARK MILLER
}

When Richard Green asked me in February if I would like to prepare a few remarks that could be read at the memorial service held at that time for Helmut in Ottawa, he did so with the suggestion that I was, as he put it, the "last surviving member of the EMC editorial team."

That's an alarming thought, and not entirely true, inasmuch as my fellow associate editors of the second edition of the Encyclopedia of Music in Canada (EMC)-Dr. Robin Elliott in Toronto and Claire Versailles in Montreal-are of course very much with us.

But yes, we've now lost all of the senior members of EMC's founding editorial teamMabel Laine first, then Gilles Potvin, Ken Winters last year, Pat Wardrop in January, and now Helmut.

I joined that team in 1975 as Helmut's researcher at the National Library. We were . . . an odd match. I was still in university and very much beholden to jazz in particular, and to pop music more generally, and, as such, worlds away from the classical traditions that were so dear to Helmut's heart. But he made me welcome, he trusted the research that I did for him, and he started me on a path to what would soon become my life's work.

He was "Dr. Kallmann" to me in those early years, and "HK" on the editorial and research memos that flew back and forth between EMC's Ottawa, Toronto and Montreal offices. In time, I came to feel that I could call him "Helmut," and if he objected to my presumption of familiarity, he never let it be known. He was, always, unfailingly politethe gentlest of gentlemen.

EMC was very much a product of its time-a time when cultural nationalism was in the air, and the funding to document the pride that we were beginning to take in this country's achievements was readily available ... a time, alas, that seems, on both counts, to have passed.

Helmut had long before understood the importance of Canada's music history-and of documenting that history. His Catalogue of Canadian Composers from 1952 and his History of Music in Canada from 1960 were seminal works, both in terms of establishing the field of study and in terms of setting the standards to which EMC, in particular, would aspire. He was, therefore, the logical person to play a central role when John Beckwith, Floyd Chalmers, Keith MacMillan, Michael Koerner, and others, each in their way, set EMC in motion more than 40 years ago. 
Helmut was of course abetted editorially in the first edition by Ken Winters and Gilles Potvin, and in the second by Gilles and to a lesser degree, Pat, Claire, Robin and me. Helmut, Ken and Gilles all had their own, designated responsibilities-Helmut's was content, Ken's was style and Gilles' was Quebec-but in truth they freely assumed each others' mantles. Those of us who worked on the first edition remember well, if ruefully, the "triangling" sessions that would find them in a room together for two or three days, once or so a month, going over every word of every article. Helmut was especially good when it came to details.

It is to Helmut's great credit as content editor-and to Ken's and Gilles', too, in their respective roles-that EMC, from the first, held its door open to all musical activity in Canada, no matter the editors' personal thoughts about any given aspect of it.

As a respectful aside, I have to say that I don't think Helmut ever quite "got" jazz; more than once, he asked me if there were scores that he could follow ...

But he understood the importance of making EMC all-embracing, all-inclusive. EMC was that much more valuable for it, and Canada has been that much richer for EMC.

It was a honour and a privilege to have worked with him on it.

MARK MiLLER is the author of 10 books about jazz, including several about jazz in Canada, and served from 1978 to 2005 as the jazz critic for The Globe and Mail. 